\title{
KONTRIBUSI PENDAPATAN IBU RUMAH TANGGA TERHADAP PENDAPATAN KELUARGA (STUDI KASUS PENJUAL AKSESORIS DI KAWASAN BUKIT KASIH KANONANG)
}

\author{
Gloria Meriam Jenevi Lopulalang \\ Mex Frans Lodwyk Sondakh \\ Melsje Yellie Memah
}

\begin{tabular}{lrr}
\hline Naskah diterima melalui Website Jurnal Ilmiah agrisosioekonomi@ unsrat.ac.id & $:$ & Minggu, 18 Oktober 2020 \\
Disetujui diterbitkan & $:$ & Selasa, 27 Oktober 2020 \\
\hline
\end{tabular}

\begin{abstract}
This study aims to see how much the contribution of housewives who sell accessories to family income in the Bukit Kasih Kanonang area. This research was conducted from November 2019 to March 2020. The data used in this study are primary data and secondary data. Primary data were obtained from interviews with accessories selling respondents using a questionnaire, while secondary data were obtained from literature and previous research. The method of determining the sample is using purposive sampling method. Retrieval of respondent data, namely housewives who still have husbands, have dependents and who work more than 10 days a month. The results showed that The contribution of the accessories selling housewives' income to family income is $33.81 \%$ of the total family income. And if seen from the age of the most respondents are aged 41-46 years, if you look at the education level of the most respondents are at the junior high school education level, if you look at the number of dependents of the respondent, the largest number of dependents is the number of dependents 2, if you look at the length of work of the respondent then It can be seen that the most respondents' length of work is 1-5 years, if seen from the highest number of working days of respondents, namely 16 working days in a month and when viewed based on the husband's job, the highest contribution of housewives is work as a photographer, with a percentage of $65.51 \%$.
\end{abstract}

Keywords: Contribution, Housewife, Income, Bukit Kasih

\begin{abstract}
ABSTRAK
Penelitian ini bertujuan untuk melihat berapa berapa besar kontribusi ibu Rumah tangga Penjual Aksesoris terhadap pendapatan keluarga di Kawasan Bukit Kasih Kanonang. Penelitian ini dilaksanakan pada bulan November 2019 sampai Maret 2020. Data yang digunakan dalam penelitian ini adalah data primer dan data sekunder. Data primer diperoleh dari wawancara kepada Responden penjual Aksesoris dengan menggunakan kuisioner Sedangkan data sekunder diperoleh dari literatur dan penelitian sebelumnya. Metode Penentuan sampel yaitu menggunakan metode Purposive Sampling. Pengambilan data responden yaitu ibu rumah tangga yang masih memiliki suami, memiliki tangunggan dan yang bekerja lebih dari 10 hari dalam satu bulan. Hasil penelitian menunjukkan bahwa kontrbusi pendapatan ibu rumah tangga penjual aksesoris terhadap pendapatan keluarga yaitu sebesar $33.81 \%$ dari total keseluruhan pendapatan keluarga. Dan jika dilihat dari umur responden terbanyak ada pada umur 41-46 tahun, jika dilhat dari Tingkat pendidikan responden terbanyak ada pada tingkat pendidikan SMP, jika dilihat dari jumlah tanggungan responden maka jumlah tanggungan terbanyak yaitu jumlah tanggungan 2 , jika dilihat dari lama bekerja responden maka dapat dilihat lama bekerja responden terbanyak ada pada 1-5 tahun, jika dilihat dari jumlah hari kerja terbanyak responden yaitu 16 hari kerja dalam satu bulan dan jika dilihat berdasarkan pekerjaan suami, kontribusi ibu rumah tangga tertinggi yaitu pekerjaan sebagai fotografer, dengan persentase $65.51 \%$.
\end{abstract}

Kata kunci : kontribusi, ibu rumah tangga, pendapatan, Bukit Kasih 


\section{PENDAHULUAN}

\section{Latar Belakang}

Keterlibatan wanita dalam kerja produktif akan menimbulkan perubahan sosial, dikarenakan salah satu wujud perubahan sosial adalah perubahan dalam kerja. Masuknya wanita dalam pasar kerja atau kerja produktif berpengaruh terhadap kegiatan ekonomi rumah tangga, sehingga dapat terjadi perubahan struktur ekonomi keluarga (Wisadirana, 2004). Aktifitas wanita untuk memperoleh penghasilan pada dasarnya untuk memenuhi kebutuhan ekonomi keluarga. Hal ini karena kondisi rumah tangga pada lapisan bawah memerlukan sumber penghasilan ganda. Industri masyarakat suatu daerah merupakan unsur penunjang bagi wisatawan sebagai konsumsi dari dampak kunjungan mereka ke destinasi pariwisata. Usaha dari industri jasa tersebut terdiri dari berbagai item yang bersifat habis seperti makanan, cenderamata, dan sebagainya. Disinilah arti pentingnya kemampuan menangkap peluang dari kemajuan pariwisata untuk meningkatkan pendapatan suatu daerah. Bukit Kasih merupakan salah satu tempat wisata Religius di Provinsi Sulawesi Utara. Bukit Kasih terletak sekitar $50 \mathrm{~km}$ arah selatan Manado, tepatnya di Desa Kanonang Kabupaten Minahasa. Keberadaan objek wisata Bukit Kasih yang ada di Desa kanonang tidak hanya menguntungkan pemerintah daerah tetapi juga bagi masyarakat di sekitar kawasan objek wisata tersebut. Bukit Kasih sebelumnya memiliki nama Bukit Doa lokasi ini sering digunakan masyarakat GMIM Bukit Sion untuk melakukan ibadah raya bersama-sama. Pembangunan Bukit Kasih pertama-tama diletakan batu pertama oleh beberapa pendeta sebagai keseriusan untuk mempergunakan Bukit Kasih sebagai tempat beribadah. Bukit Kasih adalah sebuah bukit indah unik yang terletak di kaki Gunung Soputan, Desa Kanonang Kecamatan Kawangkoan Barat Kabupaten Minahasa, sesuai namanya Bukit Kasih dimaksudkan sebagai simbol bagi kerukunan dan kedamaian kehidupan umat beragama dan sebagai pusat spiritual dan setiap pengunjung yang mengunjungi Bukit Kasih bisa melaksanakan ibadah atau berdoa di tempat ibadah sesuai agamanya masing-masing. kegiatan ekonomi yang dilakukan masyarakat Desa Kanonang di Objek Wisata Bukit Kasih Kanonang adalah dengan melakukan berbagai macam usaha seperti menjual aksesoris, foto keliling, tukang pijat, usaha rumah makan, dan juga menjual souvenir. Salah satu usaha yang dilakukan dari ibu rumah tangga di Desa Kanonang yaitu menjual Aksesoris, awal mula bukit kasih ini dibuka terdapat lebih dari 50 penjual aksesoris, namun akhir-akhir ini sudah mulai berkurang karena semakin menurunya wisatawan yang berkunjung dibukit kasih Kanonang yang mengakibatkan beberapa ibu rumah tangga penjual aksesoris berhenti melakukan usaha tersebut, namun ada juga beberapa ibu rumah tangga yang masih melakukan usaha ini karena ini meningkatkan nilai ekonomi keluarga dalam memenuhi kebutuhan keluarga seperti sandang, pangan, kesehatan dan pedidikan anakanaknya. Oleh karena itu keberadaan objek wisata Bukit Kasih Kanonang tidak hanya menguntungkan pemerintah daerah tetapi juga bagi masyarakat di sekitar kawasan objek wisata tersebut.

\section{Kontribusi}

Kontribusi berasal dari bahasa inggris yaitu Contribute, Contribution, maknanya adalah keikutsertaan, keterlibatan, melibatkan diri maupun sumbangan, berarti dalam hal ini kontribusi dapat berupa tindakan untuk melakukan sesuatu. Kontribusi pendapatan dari satu jenis kegiatan terhadap total pendapatan rumah tangga tergantung pada produktivitas faktor produksi yang digunakan dari jenis kegiatan yang bersangkutan. Stabilitas pendapatan rumah tangga, cenderung dipengaruhi dominasi sumber-sumber pendapatan. Jenis-jenis pendapatan yang berasal dari uar sektor pertanian umumnya tidak terkait dengan musim, dan dapat dilakukan setiap saat sepanjang tahun (Nurmanaf, dalam Handayani dan Artini, 2009). 


\section{Pendapatan}

Pendapatan merupakan penghasilan yang didapat dari suatu usaha dan bisa mendapat pemasukan atau modal. Menurut Sadono Sukirno (2009), dalam teori ekonomi mikro bahwa pendapatan adalah perolehan yang berasal dari biaya-biaya faktor produksi atau jasa-jasa produktif. Pengertian tersebut menunjukkan bahwa pendapatan adalah seluruh perolehan baik yang berasal dari biaya faktor produksi maupun total output yang dihasilkan untuk seluruh produksi dalam suatu perekonomian dalam jangka waktu tertentu.

\section{Pendapatan Keluarga}

Pendapatan keluarga adalah penjumlahan seluruh pemasukan keluarga yaitu pendapatan suami dan pendapatan istri. Pendapatan keluarga adalah pendapatan yang diperoleh dari suatu kegiatan usaha yang ditambahkan dengan pendapatan rumah tangga yang berasal dari luar usaha tersebut. Rendahnya pendapatan akan menyebabkan menurunya investasi dan upaya pemupukan modal. Konsep rumah tangga menunjuk pada arti ekonomi dari suatu keluarga seperti, bagaimana keluarga ini mengolah kegiatan ekonomi keluarga, pembagian kerja dan fungsi, kemudian berupa jumlah pendapatan yang diperoleh atau konsumsinya serta jenis produksi dan jasa yang dihasilkan.

\section{Peran perempuan dalam Perekonomian Keluarga}

Keterkaitan dengan upaya peningkatan pertumbuhan ekonomi dan kemandirian ekonomi masyarakat ternyata memang harus ditangani secara menyeluruh dengan memanfaatkan segala potensi yang ada. Dengan demikian aspek pemberdayaan ekonomi keluarga menjadi sebuah hal yang sangat penting memajukan kesejahteraan masyarakat. Sejak munculnya kesempatan kerja bagi perempuan menyesuaikan perannya sebagai ibu rumah tangga dan sebagai pencari nafkah. Partisipasi kerja ini tidak saja menyebabkan penambahan penghasilan rumah tangga, tetapi dengan peningkatan peran perempuan dalam mengambil keputusan.
Perempuan yang bekerja merupakan salah satu bentuk mobilitas sosial perempuan. secara normatif, pria dan wanita mempunyai status atau kedudukan serta hak dan kewajiban yang sama. Tapi dalam kondisi riil (Objektif), wanita mengalami ketertinggalan yang lebih besar dari pada pria dalam berbagai bidang kehidupan dan pembangunan. Kondisi ini menunjukkan ketidaksetaraan kedudukan antara pria dan wanita. Untuk itu, perempuan harus diberi kesempatan yang sama dengan laki-laki dalam usahanya memperoleh akses kerja dan sumberdaya lain serta pengetahuan guna mendukung kesejahteraan keluarga dalam upaya pengentasan kemiskinan.

\section{Rumusan Masalah}

Berdasarkan latar belakang, maka rumusan masalah dalam penelitian ini adalah Berapa Besar Kontribusi ibu Rumah tangga Penjual Aksesoris Terhadap Pendapatan Keluarga Di Kawasan Bukit Kasih Kanonang?

\section{Tujuan Penelitian}

Tujuan penelitian yaitu untuk mengetahui berapa besar kontribusi ibu rumah tangga Penjual Aksesoris terhadap pendapatan keluarga di Kawasan Bukit Kasih Kanonang.

\section{Manfaat Penelitian}

Penelitian ini diharapkan dapat bermanfaat bagi:

1. Bagi Ibu-ibu Penjual Aksesoris, memberikan masukan-masukan atau informasi yang berguna untuk meningkatkan pendapatan dalam menjual aksesoris.

2. Bagi Pihak lain, yaitu untuk memberikan informasi, sebagai referensi bagi pembaca maupun peneliti dalam melakukan penelitian tentang Kontribusi Pendapatan dalam keluarga.

3. Bagi Penulis, yaitu menambah pengetahuan, wawasan, dan sebagai alat ukur kemampuan teori yang diperoleh dari perkuliahan maupun literatur yang ada dalam penerapannya dengan masalah penelitian yang dihadapi. 


\section{METODE PENELITIAN}

\section{Tempat dan Waktu Penelitian}

Penelitian dilaksanakan selama 4 bulan yaitu bulan November 2019 sampai Maret 2020, mulai dari persiapan sampai penyusunan laporan. Lokasi penelitian bertempat di Objek Wisata Bukit Kasih Kanonang Kecamatan Kawangkoan Barat Kabupaten Minahasa.

\section{Metode Pengambilan Data}

Data yang dikumpulkan dalam penelitian ini adalah data primer. Data primer diperoleh dari wawancara kepada responden penjual Aksesoris dengan menggunakan kuesioner.

\section{Metode Pengambilan Sampel}

Pengambilan sampel menggunakan metode Purposive Sampling yaitu pengambilan data responden yang dilakukan secara sengaja dengan mempertimbangkan kriteria responden yaitu ibu rumah tangga yang masih memiliki suami, memiliki tangunggan dan yang bekerja lebih dari 10 hari dalam satu bulan. Dalam penelitian ini sampel yang diambil yaitu 10 responden.

\section{Konsep Pengukuran Variabel}

Variabel-variabel yang diukur dalam penelitian ini, adalah :

1. Karakteristik Responden dalam hal ini Responden penjual Aksesoris berupa Umur, Pendidikan Terakhir, Jumlah Tanggungan, lama bekerja, jumlah hari responden bekerja dalam satu minggu.

2. Pendapatan Responden, pendapatan yang didapat dari hasil menjual Aksesoris dikurangi biaya pengeluaran dalam menjual aksesoris (modal, transport, makan, dll) Rp/bulan.

3. Pendapatan Keluarga
a. Pendapatan Suami
Pendapatan yang diperoleh dari berbagai pekerjaan yang dijalankann yang dihitung berdasarkan (Rp/bulan)
b. Pendapatan Istri
Pendapatan ibu rumah tangga yang didapat dari hasil menjual aksesoris

dikurangi biaya pengeluaran dalam menjual aksesoris (Modal usaha, transportasi, biaya makan dll) Rp/bulan

c. Pendapatan Anak

Pendapatan dari anak laki-laki dan perempuan yang sudah bekerja dan yang tinggal serumah (Rp/bulan)

4. Pekerjaan Suami jika Pekerjaan Petani

a. Usahatani yang dijalankan

b. Status tanah : Milik sendiri/sakap/sewa/lainnya

c. Bagaimana sistim bagi hasilnya

d. Penggunaan sarana produksi (benih/bibit pupuk, pestisida, bahan bakar dll)

e. Modal tetap (bangunan dan jenis alat pertanian yang dimiliki, dan penggunaan tenaga kerja baik dalam keluarga maupun luar keluarga)

f. Berapa biaya lain yang dikeluarkan dalam usahatani ini

g. Jumlah produksi dan Harga Jual

\section{Metode Analisis Data}

Metode analisis data yang digunakan dalam penelitian ini adalah menggunakan analisis deskriptif yang akan dikumpulkan dan disajikan dalam bentuk tabel. Untuk menhitung pendapatan responden dihitung dengan menggunakan Rumus:

$$
\Pi=\mathbf{T R}-\mathbf{T C}
$$

Dimana

$$
\begin{aligned}
& \Pi=\text { Keuntungan } / \text { Pendapatan }(\mathrm{Rp}) \\
& \mathrm{TR}=\text { Total Penerimaan }(\mathrm{Rp}) \\
& \mathrm{TC}=\text { Total Biaya } / \text { Pengeluaran }
\end{aligned}
$$

Sedangkan untuk menghitung besarnya kontribusi ibu rumah tangga penjual aksesoris terhadap keluarga dapat dihitung menggunakan Rumus kontribusi :

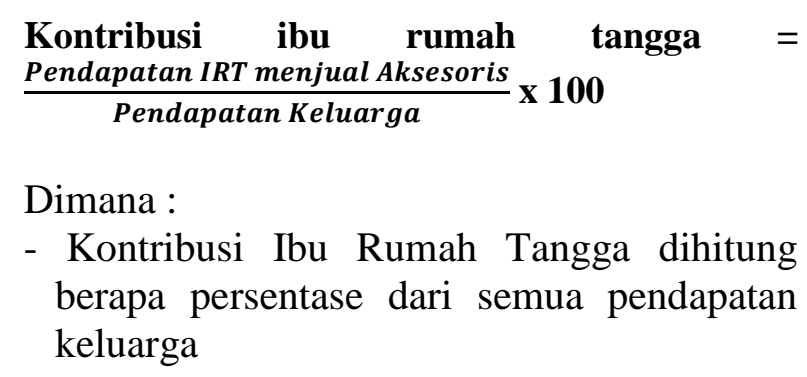


- Pendapatan keluarga $=($ Pendapatan suami + pendapatan isteri + pendapatan anak yang sudah bekerja) Pendapatan Ibu Rumah Tangga yang bekerja sebagai penjual aksessoris dihitung Rp. /bulan

\section{HASIL DAN PEMBAHASAN}

\section{Deskripsi Lokasi Penelitian \\ Keadaan Geografis Lokasi Penelitian}

Desa Kanonang Dua adalah sebuah desa yang terletak di wilayah Kecamatan Kawangkoan Barat, Kabupaten Minahasa, Provinsi Sulawesi Utara, Letak geografis Desa Kanonang Dua berada di lereng/Punggung Bukit.

\section{Jumlah penduduk}

Jumlah penduduk yang berada di Desa Kanonang Dua Kecamatan Kawangkoan Barat dapat dilihat pada Tabel 1.

\begin{tabular}{ccc}
\multicolumn{2}{c}{ Tabel 1. Jumlah penduduk } \\
\hline No & Jenis Kelamin & Jumlah Penduduk (Orang) \\
\hline 1 & Laki-laki & 419 \\
2 & Perempuan & 419 \\
& Jumlah & $\mathbf{8 3 8}$ \\
\hline \multicolumn{2}{l}{ Sumber : Data diperoleh dari Kantor Desa Kanonang Dua 2020 }
\end{tabular}

Tabel 1. Menunjukkan bahwa jumlah penduduk Desa Kanonang Dua 838 jiwa, terdiri dari 419 jiwa laki-laki dan 419 jiwa perempuan.

\section{Karakteristik Responden}

Karakteristik responden meliputi umur, tingkat pendidikan, jumlah tanggungan, lama bekerja, jumlah hari bekerja responden, jenis pekerjaan istri, Suami, dan Anak dan Pendapatan Keluarga.

\section{Umur Responden}

Umur akan dapat mempengaruhi kemampuan seseorang untuk bekerja secara fisik maupun dalam menentukan cara berpikir, dan umumnya kemampuan seseorang yang lebih mudah kerjanya lebih lama. Tingkat Umur responden dalam penelitian dapat dilihat pada Tabel 2.
Tabel 2. Jumlah Umur Responden Penjual Aksesoris di Bukit Kasih Kanonang

\begin{tabular}{cccc}
\hline No & Umur & $\begin{array}{c}\text { Jumlah } \\
\text { (orang) }\end{array}$ & Persentase (\%) \\
\hline 1 & $28-35$ & 3 & 30 \\
2 & $36-40$ & 2 & 20 \\
3 & $41-46$ & 5 & 50 \\
\hline \multicolumn{5}{r}{ Sumber : Data diolah dari data primer, 2020 }
\end{tabular}

Tabel 2 menunjukkan bahwa umur responden dengan usia 28-35 tahun berjumlah 3 orang dengan persentase 30 persen, 36-40 tahun berjumlah 2 orang dengan persentase 20 persen, dan umur 4146 tahun berjumlah 5 orang dengan persentase 50 persen.

\section{Tingkat Pendidikan}

Pendidikan merupakan salah satu hal yang sangat penting bagi manusia yang merupakan bekal dalam hidupnya. Karena dengan pendidikan yang cukup seseorang akan memiliki pola pikir yang lebih maju dan berkembang. Tingkat pendidikan dapat dilihat pada Tabel 3.

\begin{tabular}{cccc}
\multicolumn{4}{c}{$\begin{array}{c}\text { Tabel 3 Tingkat Pendidikan Responden Penjual Aksesoris } \\
\text { di Bukit Kasih Kanonang }\end{array}$} \\
\hline No & Pendidikan & Jumlah & $\begin{array}{c}\text { Persentase } \\
(\%)\end{array}$ \\
\hline 1 & SMP & 6 & 60 \\
2 & SMA & 4 & 40 \\
\hline & Jumlah & $\mathbf{1 0}$ & $\mathbf{1 0 0}$
\end{tabular}

Sumber : Data diperoleh dari data primer, 2020

Tabel 3 menunjukkan bahwa responden dengan tingkat Pendidikan SMP berjumlah 6 orang responden dengan presentase 60 persen, kemudian Pendidikan SMA yaitu 4 orang responden dengan presentase 40 persen , Hal ini menunjukkan bahwa dalam menjual Aksesoris tidak diukur dari tingginya tingkat Pendidikan respoden karena sangat bervariasi sehingga membuat responden terampil dalam menjual Aksesoris.

\section{Jumlah Tanggungan}

Jumlah tanggungan keluarga adalah banyaknya anggota keluarga yang terdiri dari anak serta orang lain yang turut serta dalam keluarga atau hidup dalam satu rumah dan makan bersama yang menjadi tanggung jawab kepala keluarga. 
Tabel 4. Jumlah Tanggungan

\begin{tabular}{cccc}
\hline No & $\begin{array}{c}\text { Jumlah } \\
\text { Tanggungan }\end{array}$ & Jumlah & Persentase(\%) \\
\hline 1 & 2 & 3 & 30 \\
2 & 3 & 6 & 60 \\
3 & 4 & 1 & 10 \\
\hline & Jumlah & $\mathbf{1 0}$ & $\mathbf{1 0 0}$ \\
\hline
\end{tabular}

Sumber : Data diperoleh dari data primer, 2020

Tabel 4 menunjukkan bahwa jumlah tanggungan 2 berjumlah 3 orang dengan persentase 30 persen, jumlah tanggungan 3 berjumlah 6 orang dengan persentase 30 persen dan jumlah tanggungan 4 berjumlah 1 orang dengan persentase 10 persen. Dengan jumlah tanggungan responden 3 orang maka mendorong responden untuk membantu pendapatan dalam keluarga, karena ibu rumah tangga yang memiliki tanggungan lebih dapat memotivasi dirinya untuk semakin giat dalam mencari nafkah.

\section{Lama Bekerja}

Lama Bekerja mempengaruhi penghasilan, apabila sudah lama menekuni pekerjaan, pastinya sudah mengetahui hal-hal baik yang dapat dilakukan agar mendapat hasil yang baik.

Tabel 5. Lama Berkerja Responden

\begin{tabular}{cccc}
\hline No & $\begin{array}{c}\text { Lama Bekerja } \\
\text { (Tahun) }\end{array}$ & $\begin{array}{c}\text { Jumlah } \\
\text { (orang) }\end{array}$ & $\begin{array}{c}\text { Persentase } \\
(\%)\end{array}$ \\
\hline 1 & $1-5$ & 5 & 50 \\
2 & $6-10$ & 2 & 20 \\
3 & $>11$ & 3 & 30 \\
\hline & Jumlah & $\mathbf{1 0}$ & $\mathbf{1 0 0}$ \\
\hline
\end{tabular}

Sumber : Data diperoleh dari data primer, 2020

Tabel 5 menunjukkan lamanya pekerjaan responden menjual aksesoris 1-5 tahun berjumlah 5 orang responden dengan persentase $50 \%$ kemudian 6-10 tahun berjumlah 2 orang responden dengan persentase $20 \%$ dan $>11$ tahun berjumlah 3 orang responden dengan persentase $30 \%$. Dengan adanya pengalaman berusaha ini akan mempermudah responden untuk mengambil keputusan yang berhubungan dengan usaha pemasaran.

\section{Jumlah Hari Responden bekerja dalam Satu bulan}

Jumlah hari responden bekerja dalam satu minggu berpengaruh terhadap pendapatan Responden semakin banyaknya hari bekerja semakin meningkatkan pendapatan Responden tersebut.

Tabel 6. Jumlah Hari Responden bekerja dalam Satu Minggu

\begin{tabular}{cccc}
\hline No & $\begin{array}{c}\text { Hari kerja } \\
\text { (Hari/bulan) }\end{array}$ & $\begin{array}{c}\text { Jumlah } \\
\text { (orang) }\end{array}$ & Persentase (\%) \\
\hline 1 & 12 & 3 & 30 \\
2 & 16 & 4 & 40 \\
3 & 20 & 3 & 30 \\
\hline & Jumlah & $\mathbf{1 0}$ & $\mathbf{1 0 0}$ \\
\hline
\end{tabular}

Sumber : Data diperoleh dari data primer, 2020

Tabel 6 menunjukkan bahwa jumlah hari kerja responden dalam satu minggu 12 hari berjumlah 3 orang Responden dengan persentase $30 \%$, selanjutnya 16 hari kerja berjumlah 4 orang responden dengan persentase $40 \%$ dan 20 hari kerja berjumlah 3 orang responden dengan persentase $30 \%$. Hal ini menunjukkan bahwa jumlah hari kerja responden yang terbanyak adalah 16 hari kerja dalam satu minggu, dalam hal ini responden bisa meluangkan waktunya dengan hal-hal yang lain seperti menggunakan waktu untuk beristirahat ketika dagangan mereka lagi sepi/tidak ada pembeli.

\section{Deskripsi Ibu Rumah Tangga Penjual Aksesoris}

Penjual Aksesoris di Objek wisata Bukit Kasih adalah orang asli Desa Kanonang. Penjual Aksesoris menjual sendiri barang dagangannya dan tidak memiliki tenaga kerja. Ibu rumah tangga penjual akseoris yang ada di Bukit Kasih menjual barang dagangannya menggunakan wadah dari plastik karena tidak memiliki kios dagang Pedagang yang ada di Bukit Kasih biasanya menawarkan Aksesoris di sekitar tugu nilai lima agama.. Ibu rumah tangga penjual Aksesoris di bukit kasih sebagian besar membuat gelang yang dijual dengan bahan baku utama yaitu batok kelapa. 
Batok kelapa yang ada di dapat dari kebun atau dari petani lain yang memiliki kebun kelapa. Selain gelang dari batok kelapa adapula gelang, kalung, cincin, dan anting-anting yang dijual dengan mengambil ke penjual aksesoris di Kota Manado. Penjualan Aksesoris awalnya berjumlah 50 orang namun akhir-akhir ini mulai menurun karena objek wisata Bukit Kasih Kanonang yang saat ini sudah mulai berkurang kunjungan dari wisatawan.

\section{Kontribusi Ibu Rumah Tangga}

Kontribusi ibu rumah tangga yang dimaksud adalah menghitung berapa besar kontribusi yang diberikan ibu rumah tangga dalam pendapatan keluarga, dengan melihat pendapatan suami, pendapatan anak, dan pendapatan yang di dapat dalam usaha lainnya.

Tabel 7. Rata-rata Harga Beli dan harga jual Per Jenis

\begin{tabular}{cccc} 
Aksesoris & Jenis Aksesoris & $\begin{array}{c}\text { Harga Beli } \\
\text { (Rp) }\end{array}$ & $\begin{array}{c}\text { Harga Jual } \\
\text { (Rp) }\end{array}$ \\
\hline 1 & Kalung Biasa & 6.000 & 25.000 \\
2 & Kalung Titanium & 25.000 & 50.000 \\
3 & Gelang Kayu & 2.000 & 10.000 \\
4 & Gelang Titanium & 10.000 & 25.000 \\
5 & Cincin & 5.000 & 15.000 \\
6 & Anting-anting & 7.000 & 15.000 \\
\hline Sumber : Data diperoleh dari Data Primer, 2020
\end{tabular}

Tabel 8. Rata-rata Biaya yang dikeluarkan dalam usaha menjual Akseosris

\begin{tabular}{cccc}
\hline $\begin{array}{c}\text { No } \\
\text { Resp }\end{array}$ & $\begin{array}{c}\text { Modal dalam } \\
\text { menjual } \\
\text { aksesoris }\end{array}$ & $\begin{array}{c}\text { Biaya } \\
\text { Transportasi, } \\
\text { makanan, dll }\end{array}$ & $\begin{array}{c}\text { Total Biaya } \\
\text { Pengeluaran }\end{array}$ \\
\hline 1 & 750.000 & 270.000 & 1.020 .000 \\
2 & 2.250 .000 & 810.000 & 3.060 .000 \\
3 & 1.500 .000 & 1.200 .000 & 2.700 .000 \\
4 & 500.000 & - & 500.000 \\
5 & 500.000 & 320.000 & 820.000 \\
6 & 500.000 & 400.000 & 900.000 \\
7 & 600.000 & 240.000 & 840.000 \\
8 & 1.500 .000 & 1.200 .000 & 2.700 .000 \\
9 & 250.000 & 240.000 & 490.000 \\
10 & 500.000 & 240.000 & 740.000 \\
\hline Jumlah & $\mathbf{8 . 8 5 0 . 0 0 0}$ & $\mathbf{4 . 9 2 0 . 0 0 0}$ & $\mathbf{1 3 . 7 7 0 . 0 0 0}$ \\
\hline Sumber: Data diperoleh dari Data Primer, 2020 &
\end{tabular}

Tabel 8, menunjukkan bahwa modal yang dikelurkan ibu-ibu penjual aksesoris yaitu mulai dari Rp.250.000 sampai Rp.2.250.000/bulan, kemudian biaya transportasi, makan dll yaitu mulai dari Rp.240.000 sampai Rp.1.200.000/bulan, tetapi ada juga responden yang tidak mengeluarkan biaya karena suami dari responden juga bekerja di kawasan wisata Bukit Kasih kanonang sebagai fotografer sehingga responden tidak perlu mengeluarkan biaya transportasi dan makan. Biaya pengeluaran dari responden yang paling besar yaitu Rp.3.060.000 dan yang paling kecil yaitu Rp.490.000.

Tabel 9. Rata-rata Penghasilan yang didapat IRT Penjual

\begin{tabular}{ccc}
\multicolumn{2}{c}{ Aksesoris } \\
$\begin{array}{c}\text { No } \\
\text { Responden }\end{array}$ & $\begin{array}{c}\text { Jumlah Aksesoris Yang } \\
\text { Terjual Per Bulan }\end{array}$ & $\begin{array}{c}\text { Penghasilan } \\
\text { Rp/Bln }\end{array}$ \\
\hline 1 & 16 & 1.500 .000 \\
2 & 51 & 5.100 .000 \\
3 & 33 & 4.050 .000 \\
4 & 10 & 1.160 .000 \\
5 & 12 & 1.380 .000 \\
6 & 12 & 1.280 .000 \\
7 & 9 & 1.080 .000 \\
8 & 48 & 4.500 .000 \\
9 & 8 & 780.000 \\
10 & 10 & 1.080 .000 \\
\hline \multicolumn{3}{c}{}
\end{tabular}

Tabel 9 menunjukkan bahwa penghasilan terbanyak responden penjual aksesoris yaitu Rp. 5.100.000 dengan jumlah yang terjual yaitu 51 Aksesoris perbulan dan penghasilan yang paling sedikit didapat responden yaitu Rp.780.000 dengan jumlah 8 aksesoris yang terjual per bulan. Hal ini menunjukkan bahwa pendapatan responden yang paling sedikit dikarenakan responden tersebut jarang menjual aksesoris dan aksesoris yang dijual hanya sedikit sehingga pendapatan yang didapat masih terlalu kecil.

\section{Pendapatan Istri}

Pendapatan merupakan sumber penghasilan seseorang yang memenuhi kebutuhan sehari-hari dan sangat penting artinya bagi kelangsungan hidup dan penghidupan seseorang secara langsung maupun tidak langsung.

\begin{tabular}{cccc}
\multicolumn{4}{c}{ Tabel 10. Jumlah Pendapatan Responden } \\
\hline $\begin{array}{c}\text { No } \\
\text { Responden }\end{array}$ & Penghasilan & $\begin{array}{c}\text { Total Biaya } \\
\text { Pengeluaran }\end{array}$ & $\begin{array}{c}\text { Rata-rata } \\
\text { Pendapatan }\end{array}$ \\
\hline 1 & 1.500 .000 & 1.020 .000 & 480.000 \\
2 & 5.100 .000 & 3.060 .000 & 2.040 .000 \\
3 & 4.050 .000 & 2.700 .000 & 1.350 .000 \\
4 & 1.160 .000 & 500.000 & 660.000 \\
5 & 1.380 .000 & 820.000 & 560.000 \\
6 & 1.280 .000 & 900.000 & 380.000 \\
7 & 1.080 .000 & 840.000 & 240.000 \\
8 & 4.500 .000 & 2.700 .000 & 1.800 .000 \\
9 & 780.000 & 490.000 & 290.000 \\
10 & 1.080 .000 & 740.000 & 340.000 \\
Jumlah & $\mathbf{2 1 . 9 1 0 . 0 0 0}$ & $\mathbf{1 3 . 7 7 0 . 0 0 0}$ & $\mathbf{8 . 1 4 0 . 0 0 0}$ \\
\hline Sumber : Data diperoleh dari data primer, 2020 & \\
\hline
\end{tabular}


Tabel 10. Menunjukkan bahwa pendapatan terbesar responden penjual aksesoris yaitu Rp.2.040.000 dan pendapatan terkecil responden penjual aksesoris yaitu Rp.290.000. Hal ini menunjukkan bahwa pendapatan responden yang tidak begitu besar dikarenakan responden tersebut tidak sepenuhnya menjual aksesoris, hanya 12 hari kerja dalam satu bulan sehingga pendapatan yang didapat tidak begitu besar.

\section{Pendapatan Suami}

Pendapatan Suami yaitu pendapatan yang didapat dari suami dari pekerjaan yang dikerjakannya.

\begin{tabular}{cccc}
\multicolumn{4}{c}{ Tabel 11. Jumlah Pendapatan menurut jenis pekerjaan } \\
\hline No & Pekerjaan & Jumlah & $\begin{array}{c}\text { Rata-rata } \\
\text { Pendapatan }\end{array}$ \\
\hline 1 & Fotografer & 2 & 600.000 \\
2 & Petani & 3 & 4.881 .000 \\
3 & Tukang Kayu & 1 & 2.000 .000 \\
4 & Bas Bangunan & 2 & 2.500 .000 \\
5 & Buruh & 1 & 2.250 .000 \\
6 & Montir & 1 & 1.500 .000 \\
\hline \multicolumn{4}{l}{ Sumber : data diperoleh dari data primer, 2020} \\
\end{tabular}

Tabel 11 menunjukkan bahwa Pekerjaan Fotografer jumlah 2 orang dengan rata-rata pendapatan Rp. 600.000, Pekerjaan petani jumlah 3 orang responden dengan rata-rata pendapatan Rp. 4.881.333, Pekerjaan Tukang kayu dengan rata-rata pendapatan 2.000.000, Pekerjaan Bas Bangunan jumlah 2 orang dengan rata-rata pendapatan Rp.2.500.000, Pekerjaan Buruh jumlah 1 orang responden dengan rata-rata pendapatan Rp.2.250.000 dan pekerjaan Montir jumlah 1 orang responden dengan rata-rata pendapatan Rp.1.500.000. Berdasarkan hasil tersebut maka dapat dilihat bahwa pendapatan terbanyak dari pekerjaan suami yaitu pekerjaan sebagai petani.

\section{Pendapatan Anak}

Pendapatan Anak adalah pendapatan yang di dapat dari anak yang sudah bekerja atau mendapatkan pendapatan lainnya berupa Beasiswa, dan lain-lain.
Tabel 12. Jumlah Pendapatan masing-masin jenis Pekerjaan Anak

\begin{tabular}{cccc}
\hline No & $\begin{array}{c}\text { Jenis } \\
\text { Pekerjaan } \\
\text { Anak }\end{array}$ & Jumlah & $\begin{array}{c}\text { Rata-rata } \\
\text { Pendapatan }\end{array}$ \\
\hline 1 & Bisnis Jual Beli & 1 & 700.000 \\
2 & Buruh Tani & 2 & 1.500 .000 \\
\hline & Jumlah & $\mathbf{3}$ & $\mathbf{2 . 2 0 0 . 0 0 0}$ \\
\hline
\end{tabular}

Sumber : Data diperoleh dari data primer, 2020

Tabel 12, menunjukkan bahwa pekerjaan anak dari responden penjual aksesoris yang bekerja yaitu mereka yang sudah berumur lebih dari 17 tahun dan sudah tidak sedang menempuh pendidikan dalam hal ini anak dari responden penjual aksesoris yang bekerja hanya ada 3 orang, karena yang paling banyak anak dari responden masih sedang menempuh pendidikan. Pekerjaan Bisnis Jual Beli yaitu jual beli handphone dengan rata-rata pendapatan Rp.700.000 per bulan, kemudian pekerjaan sebagai Buruh Tani, 2 orang responden yaitu mereka yang diberi upah dengan bekerja di kebun orang lain dan ratarata pendapatan yang didapat Rp.1.500.000 per orang.

\begin{tabular}{ccccccc}
\multicolumn{7}{c}{ Tabel 13. Rata-rata pendapatan Anggota Keluarga Berdasarkan Jenis } \\
Pekerjaan Suami
\end{tabular}

Tabel 13, Menunjukkan bahwa Rata-rata pendapatan keluarga terbesar ada pada jenis pekerjaan Suami sebagai Petani dengan total pendapatan Keluarga sebesar Rp.11.571.000 sedangkan rata-rata pendapatan terkecil ada pada jenis pekerjaan Montir yaitu sebesat Rp.1.840.000. Maka dapat dihitung kontribusi masing-masing anggota keluarga berdasarkan jenis pekerjaan suami dan dapat dilihat pada Tabel 14. 
Tabel 14. Kontribusi Anggota Keluarga Menurut Jenis

\begin{tabular}{ccccccc}
\multicolumn{8}{c}{ Pekerjaan Suami } \\
\hline No & $\begin{array}{c}\text { Jenis } \\
\text { Pekerjaan } \\
\text { Suami }\end{array}$ & $\begin{array}{c}\text { Jumlah } \\
\text { Orang }\end{array}$ & $\begin{array}{c}\text { Rata-rata } \\
\text { Pendapatan } \\
\text { Keluarga (Rp) }\end{array}$ & & \multicolumn{2}{c}{ Kontribusi (\%) } \\
\cline { 4 - 7 } & & 2 & 2.340 .000 & 34.48 & 65.51 & - \\
\hline 1 & Fotografer & 2 & 11.571 .000 & 42.18 & 44.85 & 12.96 \\
2 & Petani & 3 & 3.260 .000 & 61.34 & 17.17 & 21.47 \\
3 & Tukang Kayu & 1 & & Istri & Anak \\
4 & Bas & 2 & 5.620 .000 & 80.12 & 19.87 & - \\
& Bangunan & & & & & \\
5 & Buruh & 1 & 2.540 .000 & 88.58 & 11.41 & - \\
6 & Montir & 1 & 1.840 .000 & 81.52 & 18.47 & - \\
\hline & Jumlah & $\mathbf{1 0}$ & $\mathbf{2 4 . 0 7 1 . 0 0 0}$ & $\mathbf{5 7 . 0 4}$ & $\mathbf{3 3 . 8 1}$ & $\mathbf{9 . 1 3}$ \\
\hline
\end{tabular}

Sumber: Data diperoleh dari Data Primer, 2020

Tabel 14 menunjukkan bahwa Kontribusi ibu rumah tangga terhadap Pendapatan Keluarga yang paling besar terdapat pada jenis pekerjaan suami sebagai Fotografer yaitu sebesar $65,51 \%$. Sedangkan kontribusi Ibu rumah tangga yang paling sedikit ada pada jenis pekerjaan suami sebagai Buruh yaitu sebesar $11,41 \%$.

\section{Kontribusi Pendapatan Ibu Rumah Tangga}

Kontribusi Ibu Rumah Tangga Penjual Aksesoris dikawasan wisata Bukit Kasih Kanonang secara keseluruhan dari semua responden, dapat dilihat dari Tabel Tabulasi Pendapatan Keluarga Penjual Aksesoris di Bukit Kasih Kanonang:

Kontribusi Ibu Rumah Tangga $\frac{R p \cdot 8.140 .000}{R p \cdot 24.071 .000} \times 100$

$$
=33,81 \%
$$

Berdasarkan tabel tabulasi dapat dilihat bahwa kontribusi istri terhadap pendapatan keluarga sebesar 33,81\%. Hal ini menunjukkan bahwa kontribusi istri lebih kecil dari pada kontribusi suami untuk menunjang pendapatan keluarga. Dikarenankan para istri mengerjakan pekerjaan menjual aksesoris setelah menyelesaikan pekerjaannya dirumah sebagai ibu rumah tangga seperti memasak, mencuci dan mengurus anak dan setelah itu mengerjakan pekerjaannya sebagai penjual aksesoris.

\section{KESIMPULAN DAN SARAN}

\section{Kesimpulan}

Kontrbusi pendapatan ibu rumah tangga penjual aksesoris terhadap pendapatan keluarga yaitu sebesar $33.81 \%$ dari total keseluruhan pendapatan keluarga. Dan jika dilihat dari umur responden terbanyak ada pada umur 41-46 tahun, jika dilhat dari Tingkat pendidikan responden terbanyak ada pada tingkat pendidikan SMP, jika dilihat dari jumlah tanggungan responden maka jumlah tanggungan terbanyak yaitu jumlah tanggungan 2 , jika dilihat dari lama bekerja responden maka dapat dilihat lama bekerja responden terbanyak ada pada 1-5 tahun, jika dilihat dari jumlah hari kerja terbanyak responden yaitu 16 hari kerja dalam satu bulan dan jika dilihat berdasarkan pekerjaan suami, kontribusi ibu rumah tangga tertinggi yaitu pekerjaan sebagai fotografer, dengan persentase $65.51 \%$.

\section{Saran}

1. Lebih mengembangkan usaha menjual Aksesoris dengan cara menambah jenis aksesoris yang lebih bervariasi.

2. Mencari alternatif lain dengan cara menjual aksesoris tidak hanya di Bukit Kasih Kanonang tapi juga di tempat wisata lain sehingga dapat meningkatkan pendapatan.

3. Penelitian ini hendaknya dapat dijadikan patokan bagi ibu-ibu rumah tangga dalam mengerjakan sesuatu bahwa selain pekerjaan sebagai istri dan ibu dalam keluarga dapat juga berperan dalam usaha mencari nafkah guna menambah pendapatan keluarga. 


\section{DAFTAR PUSTAKA}

Handayani dan Artini, 2009. Kontribusi Pendapatan Ibu Rumah Tangga Pembuat Makanan Olahan Terhadap Pendapatan Keluarga. Piramida Volume V No 1 Juli. Diakses pada 10 Desember 2010.

Sukirno, Sadono. 2009. Mikro Ekonomi. Jakarta : Raja Grafindo Persada.
Wisadirana. (2004). Kontribusi pendapatan tenaga kerja wanita pada usaha pembuatan tempe terhadap pendapatan keluarga (Studi Kasus : Kelurahan Tanjung Sari, Kecamatan Medan Selayang) Skripsi A. A Murad D (2016). Diakses pada 1 Desember 2019. 